\title{
The Use of the Three Sided Flap in the Maxillary
}

\section{Anterior Segmental Osteotomy}

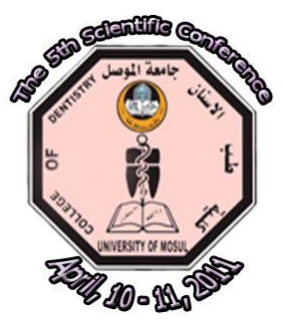

\section{ABSTRACT}

Aims: Evaluation of new surgical approach to anterior maxillary segmental osteotomy (AMSO). Materials and Methods: Twenty five jaws operated on for AMSO with the use of three sided flap, using sulcular type of incision of the soft tissues to access the bone to be osteotomized. Patients underwent surgical correction under general anesthesia and follow up extended postoperatively till complete healing process occurred nearly six months later. Results: From the total number of cases, twenty four jaws healed properly; and only one jaw (premaxilla) was lost due to necrosis of bone with loss of the associated teeth due to accidental and complete detachment of bone from the overlying soft tissues during surgery, although this procedure offers the avoidance of loss of any part of the soft tissue envelope. Conclusion: The three sided sulcular incision doesn't interfere with blood supply of both hard \& soft tissues, with many advantages over other types of access flaps.

\section{الخلاصة}

استعمال السدلة الثلاثية الأضلاع في العمليات الجراحية التقويمية للمنطقة الأمامية

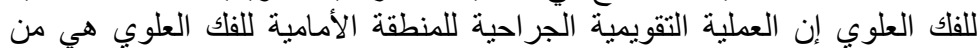

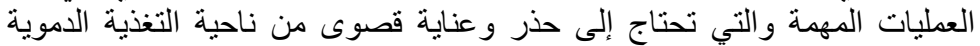

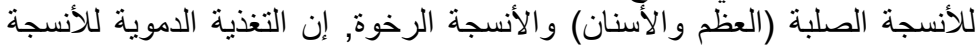

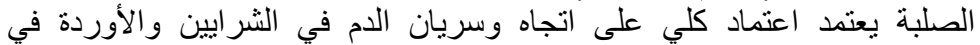

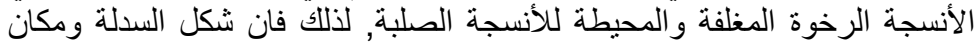

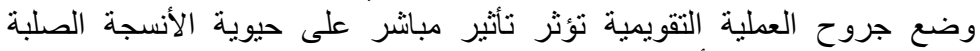

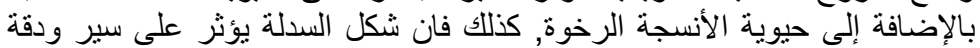

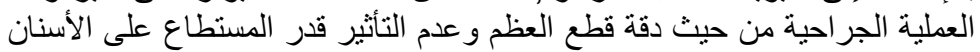

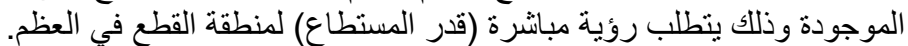

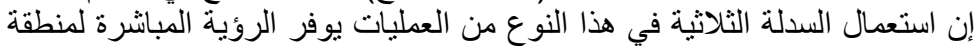

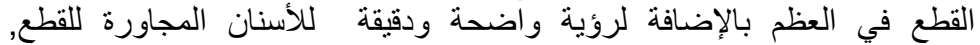

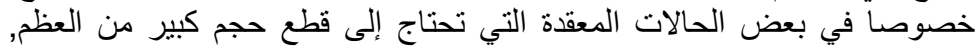

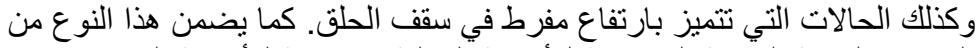

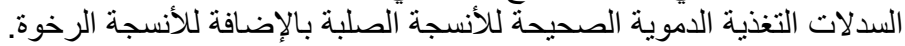

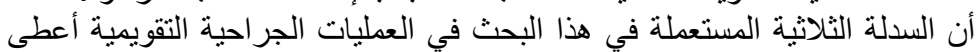

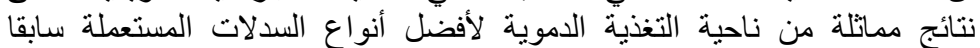

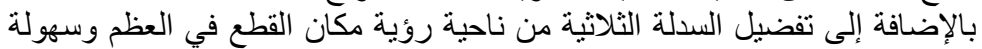
معالجة الأنسجة الرخوة والصلبة وقلة الأضر ار المصاحبة للعطلية الجر احية.

Key Words: Three sided flap, anterior maxillary segmental osteotomy.

Journal of the $5^{\text {th }}$ Scientific Conference of Dentistry College, Apr. 2011
Bassam F. Yasen ${ }^{1}$ (B.D.S, FIBMS); Ayad M. Isma el ${ }^{2}$ $(F D S R C)$; Ne`am F. Yasen ${ }^{3}$ (B.D.S, M.SC.)
Department Oral and Maxillofacial Surgery, Al-Salam Teaching Hospital, Nineveh Directorate, $\mathrm{MOH}$, Iraq;

Department Oral and Maxillofacial Surgery, Special Surgeries Hospital, Baghdad Health Directorate, MOH, Iraq; Department of Prevention, Orthodontics, and Pedodontics, College of Dentistry, University of Mosul, Mosul, Iraq 


\section{INTRODUCTION}

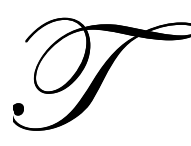

he first account of an anterior maxillary segmental osteotomy was probably from Cohn-Stock (1921). The first consideration for the AMSO is to reposition and fix the fragment (premaxilla) in the desired position without jeopardizing the vascular pedicle ${ }^{(1,2)}$. The vascular pedicle is either predominant buccally or palataly; inadvertent cutting of the pedicle, stretching or folding of the mucoperiosteal flap that contains the vascular pedicle should be avoided.

Mohnac and Henry contended that the posterior palatine and incisive canal blood vessels should be kept intact to assure adequate blood supply to the anterior maxillary fragment ${ }^{(3,4,5,6)}$.

Under clinically simulated conditions, there was no detectable compromise of blood supply to the sectioned fragments. Intraosseous and soft tissue collateral circulation and the freely anatomizing gingival, palatal, floor of the nose, and periodontal plexuses, permit many variations of the anterior maxillary osteotomy technique without disturbance to the integrity of the blood supply to the anterior maxillary segment. The findings indicated that surgical techniques were biologically sound as evidenced by the general vascularization of the soft and hard tissues. When the bone cuts were made $5 \mathrm{~mm}$ or more away from the apices of the teeth, there was no interruption of pulpal circulation. When the labial mucoperiosteum was completely reflected from the anterior alveolar region, there was enough collateral circulation from the palatal vessels to replace the interrupted circulation to bone ${ }^{(7)}$.

The primary blood supply for the alveolar mucosa is derived from the supraperiosteal vasculature that runs parallel to the long axis of the teeth ${ }^{(8,9)}$.

As long as one of the main arterial supplyers of the buccal soft tissues of the maxilla, which are the infraorbital vessels, reflection of the buccal maxillary mucoperiosteum from its underlying bone with maintenance of a wide flap base will not lead to soft tissue necrosis. The primary blood supply to the maxillary buccal alveolus, periodontium, and teeth is from the posterior superior alveolar and infraorbital vessels; whereas the primary supply to the palate and palatal alveolus are the greater palatine vessels ${ }^{(10,11,12)}$.

\section{MATERIALS AND METHODS}

Patients: Twenty five patient's jaws were operated on in this study, eleven male and thirteen female patients.

After thorough clinical examination and investigations, with discussion of both the type of problem and type of treatment with the patients himself, patients agreed signing the consent form to underwent surgical correction for his/her deformity under general anesthesia. Jaws (maxillae) were operated for AMSO by osteotomising the anterior part and moving it in different directions, and then tilting movements using the three sided sulcular soft tissue flap were performed to approach the underlying bone.

Investigations: The following investigations were done:

- Hematological tests including hemoglobin level, serum urea, serum creatinin, blood group, packed corpuscular volume.

- Radiographs including postero-anterior chest radiograph, cephalometric view with, occipito-mentum view, orthopantomographic view and periapical radiographs were done.

- Study casts with jaws relations were taken.

- Pre and postoperative photographs. (Figures 1,2,3 and 4)

- Preoperative tracing of the cephalometric radiographs was done on transparent paper.

\section{Surgery:}




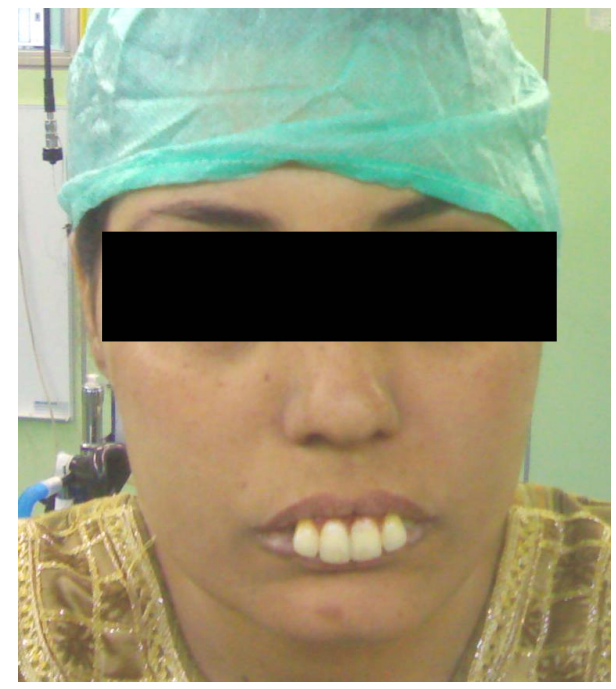

Figure 1

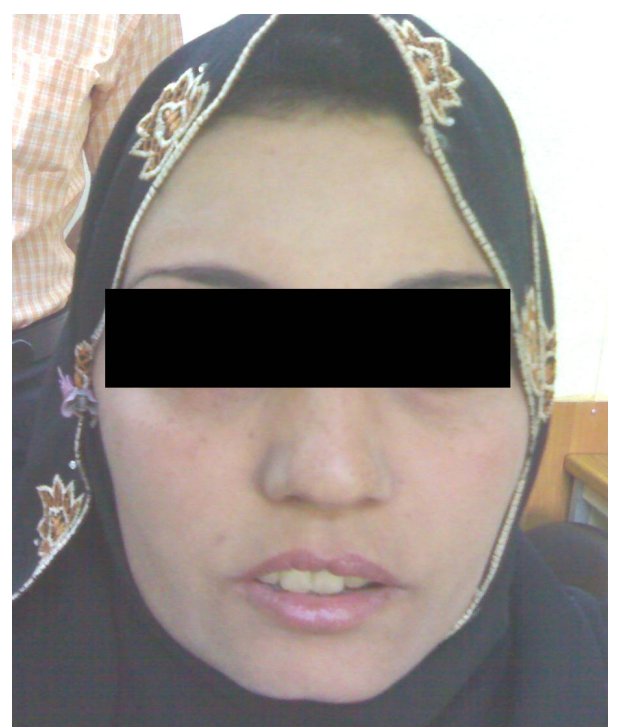

Figure 3

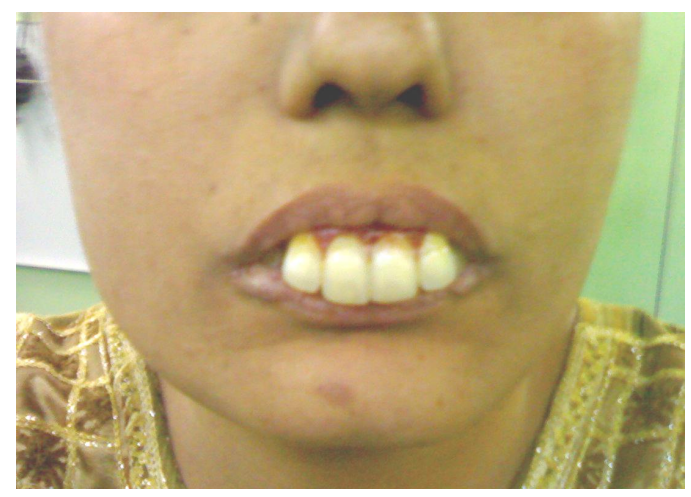

Figure 2

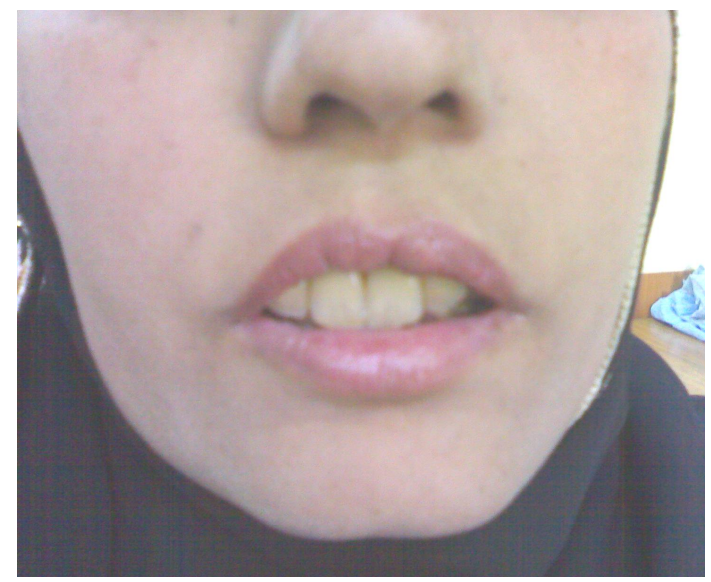

Figure 4

Anesthesia: Patients were operated under general anesthesia.

Surgical Instruments: Surgical instruments were used for soft tissue reflection, bone cutting, suturing and fixation (intraosseous) of bone at the end of surgery.

Incision: Following extraction of the first premolar teeth when needed, the incision started from the distal area of the second premolar (the vertical incision) on one side of the jaw and continued with the horizontal (sulcular) incision extended along the cervical areas of the teeth to reach the distal area of the second premolar on the contra-lateral side of the jaw, then ended with another vertical incision distal to the second premolar. 
Soft Tissue Reflection and Bone Sectioning: Was done to expose the entire bony area to be osteotomized, in addition to the standing associated teeth. Direct visualizing of the bone to be sectioned and associated teeth was easily performed following sectioning of the bone in the required area. The bony segments were moved to the previously planned position (Figure 5, 6 and 7).

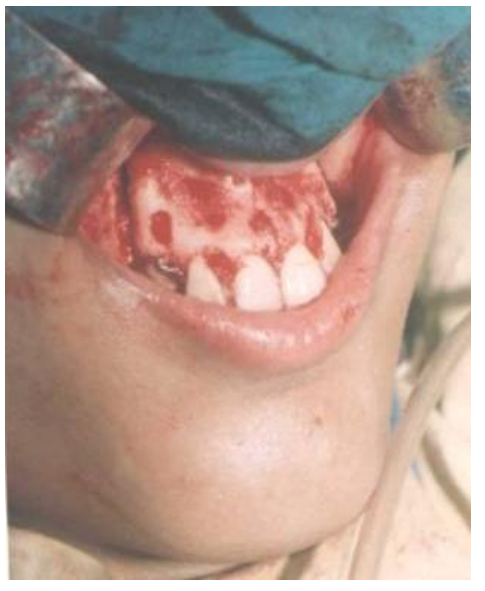

Figure 5

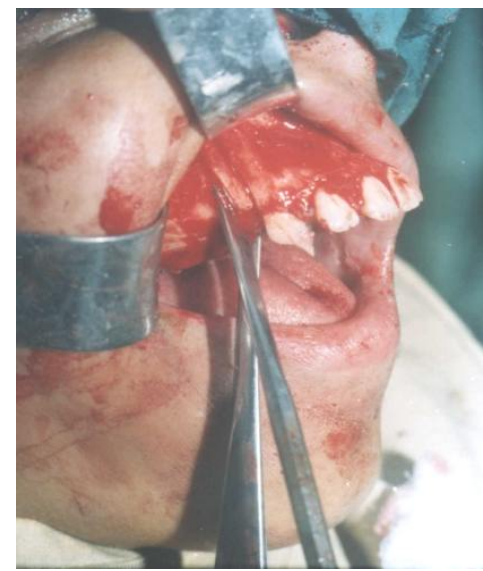

Figure 6

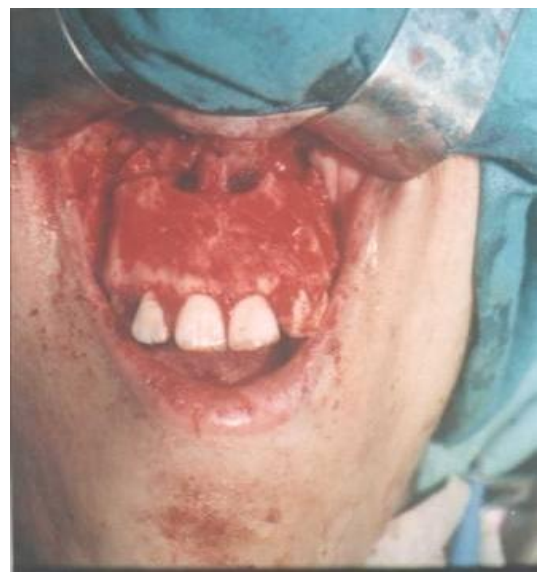

Figure 7

Fixation: For the segments were done by plating or by intraosseous wiring, and combined with intermaxillary fixation (for two weeks).

Wound Closure: Wound was closed with interrupted silk suture (0/5 black silk), following repositioning of the flap adequately. The patient recovered from the general anesthesia, intermaxillary fixation was performed for the patient on the first day following surgery.

Follow up: Regular daily monitoring of the patients was performed from the day of surgery until the day of patient discharge from the hospital (two weeks post operatively). During this period, any abnormal change in the color of the soft tissue or the teeth was observed; any signs of infection like redness, abnormal swelling, exudative discharge from the area of surgery, mobility of the segments or teeth, or fever was recorded. The patients then were monitored weekly from the day of discharge from hospital up to two weeks following removal of dental wiring.

\section{RESULTS}

Healing process was smooth with no complications (no abnormal signs or symptoms were recorded) for the twenty four jaws that had been operated on. Intermaxillary fixation was performed from the day following the day of surgery till the fifteenth day following surgery, at which it was changed into intramaxillary fixation until the day forte-five following the day of surgery. By then, complete removal of the dental wiring was done, with adequate healing of both soft and hard tissues in the operated area (Table 1) 
Table (1): Follow Up Results

\begin{tabular}{|c|ccccccc}
\hline & $\begin{array}{c}\text { Abnormal } \\
\text { Change in } \\
\text { Flap } \\
\text { Color }\end{array}$ & $\begin{array}{c}\text { Abnormal } \\
\text { Change in } \\
\text { the Color } \\
\text { Of Teeth }\end{array}$ & $\begin{array}{c}\text { Mobility } \\
\text { of } \\
\text { Segments } \\
\text { or Teeth }\end{array}$ & $\begin{array}{c}\text { Redness } \\
\text { of Flap }\end{array}$ & $\begin{array}{c}\text { Abnormal } \\
\text { Swelling }\end{array}$ & $\begin{array}{c}\text { Fluid } \\
\text { Discharge } \\
\text { from the } \\
\text { Flap }\end{array}$ & Fever \\
\hline $\begin{array}{c}\mathbf{1}^{\text {st }} \text { Day } \\
\text { Postoperatively } \\
\mathbf{1}^{\text {st }} \text { Week }\end{array}$ & 25 & 0 & 0 & 25 & 24 & 0 & 25 \\
$\begin{array}{c}\text { Postoperatively } \\
\mathbf{2}^{\text {nd }} \text { Week }\end{array}$ & 1 & 1 & 0 & 1 & 0 & 1 & 0 \\
$\begin{array}{c}\text { Postoperatively } \\
\mathbf{3}^{\text {rd }} \text { Week }\end{array}$ & 1 & 1 & 1 & 0 & 0 & 1 & 0 \\
$\begin{array}{c}\text { Postoperatively } \\
4^{\text {th }} \mathbf{- 6}^{\text {th }} \text { Week } \\
\text { Postoperatively }\end{array}$ & 1 & 1 & 1 & 1 & 0 & 1 & 0 \\
\hline
\end{tabular}

In only one female patient jaw, the bony premaxilla was completely and accidentally separated per-operatively from its attached soft tissues by forceful unaware traction of the bone during soft tissue reflection, osteomising and fixation procedure. It showed excessive mobility of the moved segment and the associated teeth showed very obvious change in the color of the teeth despite conservative management (systemic antibiotic, local application of iodoform gauze and maintenance of adequate oral hygiene) of the affected premaxilla, so the patient unfortunately completely lost the premaxilla and the associated teeth but without loss of any part of the overlying soft tissues; suturing of the labial and palatal mucoperiosteum together was done following removal of the necrotic premaxilla and teeth, with reconstructive surgeries afterward (Figures 8 and 9).

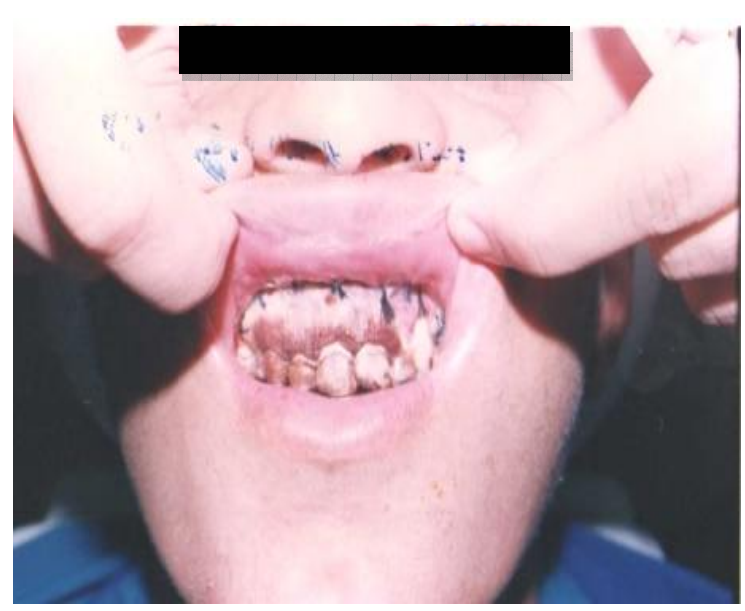

Figure 8

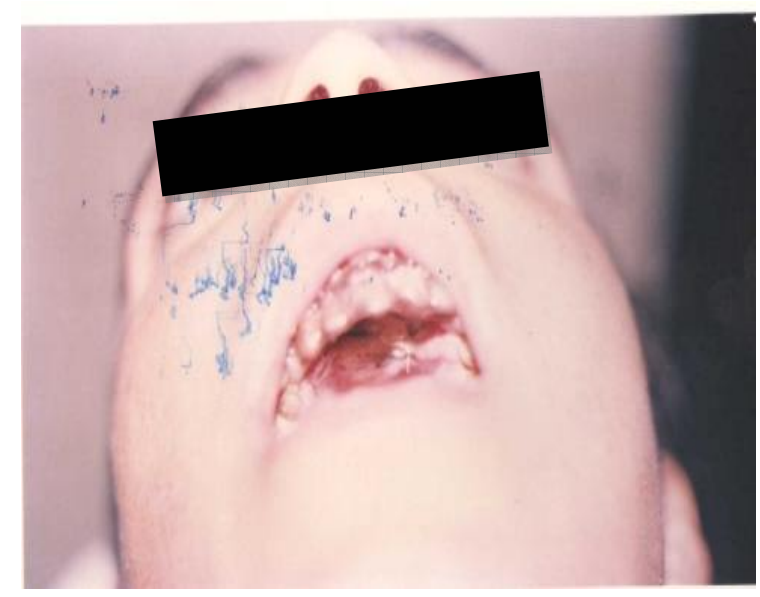

Figure 9 


\section{DISCUSSION AND CONCLUSIONS}

Regarding the maxillary jaw, this approach dose not jeopardize the blood supply of the moved premaxilla, in addition, the presence of a strip of attached and mobile mucosa to the osteotomized segment (like in Wonderer procedure) does not add any beneficial advantage to the blood supply, as this soft tissue will take its blood supply from the underlying osteotomized bony segment. This soft tissues will add a harmful effect to the condition in case of injury to the principle arterial supply ${ }^{(13)}$, while in the three sided soft tissue approach, the soft tissue will be preserved and will help in the future reconstructive procedure, in case of inadvertent complication.

The advantages of this technique are: direct visualization and approach to the whole area to be osteotomized (bone and teeth), the final suturing lines will be supported by intact bone and the suture line dose not cross osteotomy areas only for a short distance, ability of harvesting good size of bone from the area of extraction when the extraction is mandatory to be used later on as bone graft in the areas required and direct access to the floor of the nose and nasal septum when down fracturing the premaxilla, which enables osteotomising the estimated segment of bone easily, which is very difficult to be accomplished by other procedures, especially in highly arched palate ${ }^{(14,15)}$. In addition, perfect osteotomy cuts can be made in alveolar bone in cases that don't need tooth extraction without dental injury, minimal extraction trauma is performed in the cases that needs dental extraction because of direct access to the tooth and its socket, the ability to excise excess soft tissue easily which results following moving of bone, especially in the set back procedure, minimal trauma to the vital structures in the vicinity of osteotomy cuts, which are the greater palatine artery and the adjacent teeth, avoidance of releasing of the muscle from its attached periosteum during incision and reflection with resultant maintenance of soft tissue relation to the underlying moved bony segment following adequate suturing.

\section{REFERENCES}

1. Dennis T. L. Vascular Complications Associated with Orthognathic Surgery, Oral. Maxillofacial Surg Clin Nor Am. 1997; 9 (2): 22.

2. Bell W.H. Revascularization and Bone Healing after Anterior Maxillary Osteotomy; a Study Using Adult Rhesus Monkeys. J.Oral Surg. 1969; 3:43-9.

3. Augustein A. Flap Design for Periapical Surgery. Practical Endodontics. 1992; 6: 23-8.

4. O`Ryan F. Nasal Anatomy and Maxillary Surgery, Esthetic and Anatomic Principles. The International Journal of adult orthodontics and orthognathic surgery. 1989; 4:1-8.

5. Rhinelander F.W. and Baragry R.A. Microangiography in Bone Healing Following Undisplaced Closed Fractures. Journal of Bone and Joint Surgery. 1962; 44:1273.

6. Wray J.B. \& Spencer M.P. The Vasodilatory Response to Skeletal Trauma. Plastic \& Reconstructive Surgery. Surgical Forum 1960.

7. Epker BN. Vascular Consideration in Orthognathic Surgery. Journal of Oral Surg. 1984; 4:34-6.

8. Meyer MW and Cavanaugh GD. Blood flow changes after Orthognathic Surgery: Maxillary and Mandibular Subapical Ostectomy. Journal of Oral Surgery. 1976; 10:66-2.

9. Epker BN. A Modified Anterior Maxillary Osteotomy. Journal o Oral and Maxillofacial Surger. 1981; 7:89-4.

10. Epker BN and Wolford LM. Dentofacial Deformities. Surgical Orthodontic Correction. 1980; 5:30-4.

11. Broune RM and Freihofer HPM. Long -Term Results on the Quadrangular Osteotomy. Int J Oral Maxillofacial Surg. 1992; 21:192.

12. De Mol van Otterloo JJ, Tuinzing DB, Greebe RB. Intra- \& Early Postoperative Complications of the Le Fort I Osteotomy: A Retrospective Study on 410 Cases. Journal of Craniomaxillofacial Surgery, 1991; 19:217.

13. Drommer R. Selective Angiographic Studies Prior to Le Fort I Osteotomy in Patients with Cleft Lip \& Palate. Journal of Maxillofacial Surgery. 1979; 7:264.

14. Freihofer HP and Brouns J. A Reappraisal of Midfacial Movements". Oral \& Maxillofacial Surg Clin of Nor Am. 1990; 2:761.

15. Kaban BL and Pogrel MA. Complication in Oral and Maxillofacial Surgery. W.B. Sanders Company. 1997; $13: 218-219$. 